\title{
ANALISIS EFEKTIVITAS DAN KONTRIBUSI PENERIMAAN PAJAK BUMI DAN BANGUNAN (PBB) DAN PAJAK PENGHASILAN (PPH) TERHADAP PENDAPATAN NEGARA TAHUN 2007-2017
}

\author{
Muhammad Ismayadie \\ Universitas Bangka Belitung \\ Email: mismayadie@gmail.com
}

\begin{abstract}
ABSTRAK: Jurnal ini menganalisis efektivitas dan kontribusi penerimaan pajak bumi dan bangunan dan pajak penghasilan terhadap pendapatan negara. Adapun beberapa variabel yang digunakan pada penelitian ini adalah pajak bumi dan bangunan, pajak penghasilan dan pendapatan negara. Dengan menggunakan metode analisis efektivitas dan kontribusi, jurnal ini menemukan bahwa rata - rata efektivitas pajak bumi dan bangunan adalah 98 persen dengan kategori efektif dan rata-rata kontribusi pajak bumi dan bangunan adalah sebesar 2 persen yang menurut kriteria berarti sangat kurang atau rendah dikarenakan pajak bumi dan bangunan memiliki jumlah yang relatif kecil sebagai penerimaan negara sedangkan ratarata efektivitas pajak penghasilan sebesar 95 persen dengan kategori efektif dan rata-rata kontribusi pajak penghasilan adalah sebesar 37 persen yang menurut kriteria berarti cukup baik sebab pajak penghasilan merupakan pajak dengan nilai terbesar untuk penerimaan negara. Rata-rata pajak yang nilai diatas 90 persen menujukkan kecilnya tunggakan pajak dan penghindaran pajak oleh si wajib pajak, dimana rata-rata wajib pajak dapat memenuhi kewajiban pajak.
\end{abstract}

Kata kunci: Efektivitas; Kontribusi; Pajak Bumi dan Bangunan; Pajak Penghasilan; Pendapatan Negara

\section{PENDAHULUAN}

\subsection{Latar Belakang}

Pendapatan negara adalah jumlah pendapatan yang diterima oleh faktor produksi yang digunakan untuk memperoduksi barang dan jasa dalam suatu tahun tertentu. Pendapatan nasional dapat juga diartikan sebagai nilai barang dan jasa yang dihasilkan dalam suatu negara (Sukirno, 2008). Dalam struktur pendapatan negara, Indonesia mempunyai banyak penerimaan dari berbagai sektor diantaranya adalah sektor Minyak dan Gas serta Non Minyak dan Gas (contohnya adalah penerimaan dari sektor pajak, retribusi, hibah, dan lainlain). Berikut adalah gambar pendapatan negara di Indonesia. 


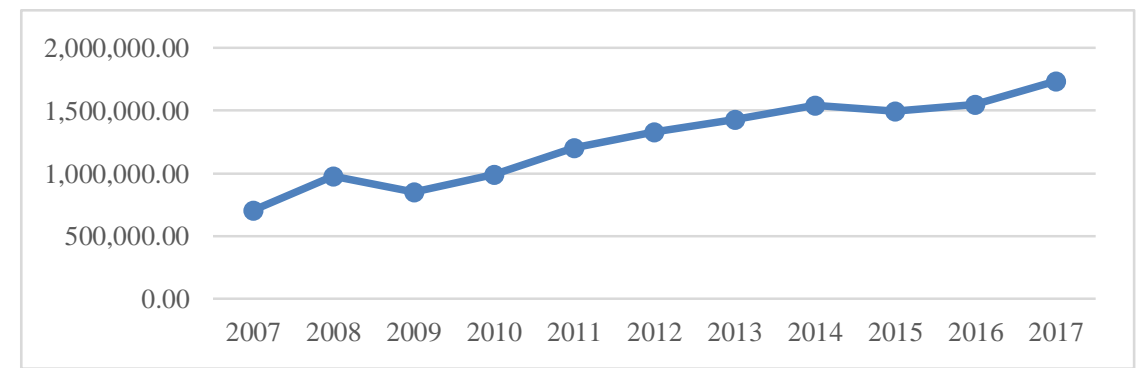

Gambar 1.1 Pendapatan Negara Indonesia Tahun 2007-2017 (Miliyar Rupiah)

Sumber : Badan Pusat Statistik (2018)

Berdasarkan gambar 1.1 menunjukkan bahwa pendapatan negara hampir setiap tahunnya mengalami peningkatan dalam kurun waktu 10 tahun terakhir. Dimana pendapatan tertinggi pada tahun 2017 sebesar 1.732.952,00 (Miliyar rupiah) dan terendah pada tahun 2007 sebesar 706.108,00 (Miliyar rupiah).

Pajak merupakan salah satu sumber penerimaan negara yang sangat penting artinya bagi pelaksanaan dan peningkatan pembangunan nasional, yang merupakan pengamalan Pancasila yang bertujuan untuk meningkatkan kemakmuran dan kesejahteraan masyarakat (Mokamat, 2009).

Pengertian PBB menurut Undang-undang PBB adalah iuran yang dikenakan terhadap pemilik, pemegang kekuasaan, penyewa dan yang memperoleh manfaat dari bumi dan atau bangunan. Pengertian bumi disini adalah termasuk permukaan bumi dan tubuh bumi yang ada dibawahnya. Bangunan adalah konstruksi teknik yang ditanam atau diletakkan secara tetap pada tanah dan atau perairan dan digunakan sebagai tempat tinggal atau tempat berusaha. Dasar hukumnya adalah UndangUndang Nomor 12 Tahun 1985 yang telah diubah menjadi Undang-Undang Nomor 12 Tahun 1994. Berikut adalah gambar realisasi dan target penerimaan pajak bumi dan bangunan di Indonesia.

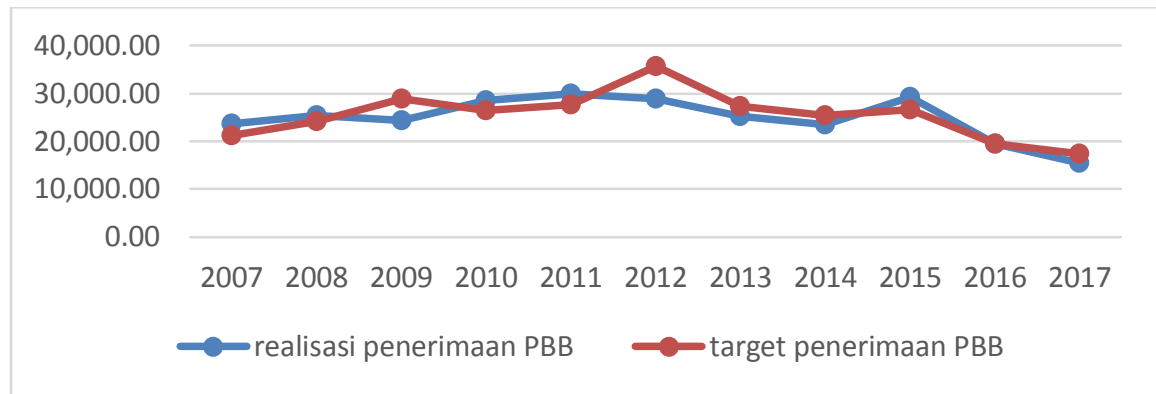

Gambar 1.2 Realisasi dan Target Penerimaan Pajak Bumi dan Bangunan di Indonesia

Tahun 2007-2017 (Miliyar Rupiah)

Sumber : Badan Pusat Statistik (2018)

Berdasarkan gambar 1.2 menunjukkan bahwa penerimaan PBB mengalami fluktuasi dimana penerimaan PBB tertinggi pada tahun 2015 sebesar 29.250,05 (Miliyar rupiah) dan terendah pada tahun 2017 sebesar 15.412,10 (Miliyar rupiah).

Menurut Rimsky K. Judisseno (1997) pajak penghasilan adalah suatu pungutan resmi yang ditujukan kepada masyarakat yang berpenghasilan atau atas penghasilan yang diterima atau di perolehnya dalam tahun pajak untuk kepentingan negara dan masyarakat dalam hidup berbangsa dan bernegara sebagai suatu kewjiban yang harus dilaksanakannya. 


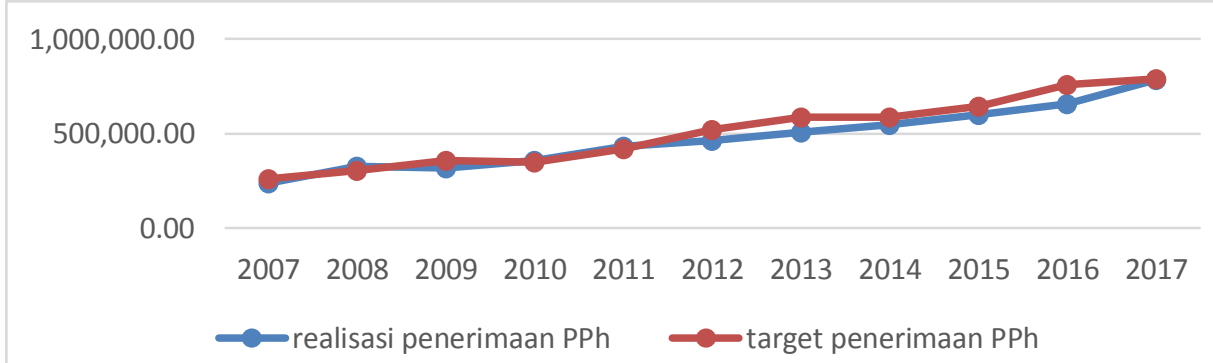

Gambar 1.3 Realisasi dan Target Penerimaan Pajak Penghasilan di Indonesia Tahun 2007 2017 (Milyar rupiah)

Sumber : Badan Pusat Statistik (2018)

Berdasarkan gambar 1.3 menunjukkan bahwa penerimaan pajak penghasilan mengalami peningkatan setiap tahunnya dimana penerimaan pajak penghasilan tertinggi pada tahun 2017 sebesar 783.970,30 (Miliyar rupiah) dan terendah pada tahun 2007 sebesar 238.431,00 (Miliyar rupiah).

Penelitian ini dilakukan untuk melihat perbandingan antara penerimaan pajak penghasilan yang peroleh dari wajib pajak yang berpenghasilan dan pajak bumi dan bangunan yang diperoleh dari wajib pajak yang memliki hak dan memperoleh keuntungan atas tanah dan bangunan tersebut yang digunakan sebagai penerimaan negara. Penerimaan dari pajak penghasilan dan pajak bumi dan bangunan dapat digunakan untuk meningkatkan kesejahtraan masyarakat seperti menyediakan fasilitas kesehatan, pendidikan, infrastruktur, pelayanan publik lainnya. Penerimaan pajak penghasilan dan pajak bumi dan bangunan dapat di ukur melalui tingkat efektivitas dan kontribusi, yang dapat menujukkan besaran tunggakan pajak, penghindaran pajak oleh si wajib pajak dan menjadi tolak ukur keberhasilan pemerintah yang akan menjadi acuan pemerintah untuk membuat kebijakan yang akan datang.

\subsection{Rumusan Masalah}

Bagaimana perbedaan dan tingkat dari nilai efektivitas dan kontribusi penerimaan pajak bumi dan bangunan dan penerimaan pajak penghasilan pada pemerintah dari tahun 2007 sampai dengan 2017?

\subsection{Tujuan Penelitian}

Adapun tujuan penelitian ini adalah untuk mengetahui perbedaan dan tingkat dari nilai efektivitas dan kontribusi penerimaan pajak bumi dan bangunan dan penerimaan pajak penghasilan pada pemerintah dari tahun 2007 sampai dengan 2017.

\section{TINJAUAN PUSTAKA}

\subsection{Landasan Teori}

\subsubsection{Pengertian Pajak}

Pajak merupakan salah satu sumber penerimaan negara yang sangat penting artinya bagi pelaksanaan dan peningkatan pembangunan nasional, yang merupakan pengamalan Pancasila yang bertujuan untuk meningkatkan kemakmuran dan kesejahteraan masyarakat. Dengan demikian sistem perpajakan terus disempurnakan, pemungutan pajak diintensifkan, dan aparat perpajakan/pengelola juga harus makin mampu dan bersih sehingga dapat mewujudkan peran yang besar dalam pembangunan nasional (Mokamat, 2009). 


\subsubsection{Pajak Bumi dan Bangunan}

Berdasarkan Undang-Undang no 12 tahun 1994 pajak bumi dan bangunan (PBB) adalah pajak negara yang dikenakan terhadap Bumi dan Bangunan. PBB adalah pajak yang bersifat kebendaan dalam arti besarnya pajak terutang ditentukan oleh keadaan objek yaitu bumi/tanah dan atau bangunan.

Pajak Bumi dan Bangunan (PBB) merupakan jenis pajak yang sepenuhnya diatur oleh pemerintah dalam menentukan besar pajaknya (menganut sistem pemungutan official assessment system). Pajak ini bersifat kebendaan dalam arti besarnya pajak terutang ditentukan oleh keadaan objek yaitu bumi/tanah dan/atau bangunan. Di sini keadaan subyek (siapa yang membayar) tidak ikut menentukan besarnya pajak.

1. Subjek / Wajib Pajak Bumi dan Bangunan

Yang menjadi subjek pajak PBB adalah orang pribadi atau badan yang secara nyata mempunyai suatu hak atas bumi dan /bangunan. Jangkauan subjek dalam Undang-Undang Pajak Bumi dan Bangunan sangat luas, karena meliputi orang atau badan yang memiliki, menguasai dan /atau memperoleh manfaat atas bumi dan / atau bangunan.Ini berarti meliputi antara lain pemilik, penghuni, pengontrak, penggarap, pemakai dan penyewa atas bumi dan /bangunan. Oleh karena sangat luasnya maksud yang terkandung dalam Undang-Undang Pajak Bumi dan Bangunan, yang menjadi subjek pajak belum tentu menjadi wajib pajak. Sebab subjek pajak akan /baru menjadi wajib pajak apabila sudah memenuhi syarat-syarat objektif atau sudah mempunyai objek PBB yang dikenakan pajak. Yang berarti subjek pajak mempunyai hak atas objek yang dikenakan pajak (memiliki, menguasai, memperoleh manfaat dari objek kena pajak). Jika suatu objek pajak belum diketahui secara pasti siapa wajib pajaknya, maka Dirjen Pajak oleh undang-undang diberi wewenang untuk menunjuk dan menetapkan subjek pajak sebagai wajib pajak. Beberapa ketentuan khusus tentang siapa yang menjadi subjek pajak dalam hal ini adalah:

Jika subjek pajak memanfaatkan dan menggunakan bumi dan /bangunan milik orang lain bukan karena suatu hak atau perjanjian, maka subjek pajak tersebut ditetapkan sebagai wajib pajak.

Jika objek pajak masih dalam sengketa, maka orang /badan yang memanfaatkan objek pajak tersebut ditetapkan sebagai wajib pajak.

Apabila subjek pajak sudah memberi kuasa kepada orang/badan untuk merawat (mengurus) bumi dan bangunannya disebabkan suatu hal, maka orang/badan yang telah diberi kuasa dapat ditetapkan sebagai wajib pajak.

2. Objek Pajak Bumi dan Bangunan

Dalam undang-undang Pajak Bumi dan Bangunan tahun 1985 menyebutkan bahwa yang menjadi objek Pajak Bumi dan Bangunan adalah bumi dan /bangunan. Keduanya (bumi dan bangunan) dapat berdiri sendiri (bumi saja atau bangunan saja) maupun secara bersamasama sebagai objek yang dapat dikenakan Pajak Bumi dan Bangunan. Pengertian bumi dijelaskan meliputi permukaan bumi dan juga tubuh bumi yang ada di bawahnya.

Apa yang disebut "permukaan bumi" di sini tak lain adalah tanah itu sendiri yang meliputi perairan. Sedangkan "tubuh bumi" adalah apa-apa yang berada di dalam bumi dan yang berada di bawah air. Apa yang disebut dengan air (perairan) disini mencakup perairan pedalaman (termasuk rawa-rawa) serta laut wilayah Indonesia.

Jadi yang menjadi objek Pajak Bumi dan Bangunan itu adalah tanah, air (perairan) dan tubuh bumi. Contoh : sawah, ladang, kebun, pekarangan, tambang, dll. Bangunan sebagai objek Pajak Bumi dan Bangunan adalah Konstruksi teknik yang ditanamkan atau dilekatkan secara tetap pada tanah dan/atau perairan di wilayah Republik Indonesia yang diperuntukkan sebagai tempat tinggal atau tempat usaha. Yang termasuk dalam pengertian bangunan dalam penjelasan Undang-Undang Pajak Bumi dan Bangunan adalah: 
1. Jalan lingkungan yang teletak dalam suatu kompleks bangunan.

2. Kolam renang.

3. Galangan kapal, dan dermaga.

4. Jalan tol.

5. Pagar mewah.

6. Taman mewah.

7. Tempat penampungan / kilang minyak.

8. Tempat olah raga, dan lain-lain.

Apabila seseorang atau badan memiliki rumah (bangunan) yang berada di atas tanah orang lain sehingga pemilik bangunan terpisah dari pemilik tanah. Undang-undang Pajak Bumi Bangunan memungkinkan pemilik bangunan dikenakan pajak sendiri terlepas dari pajak yang dikenakan pada pemilik tanah.

\subsubsection{Pajak Penghasilan}

menurut Rimsky K. Judisseno (1997) pajak penghasilan adalah suatu pungutan resmi yang ditujukan kepada masyarakat yang berpenghasilan atau atas penghasilan yang diterima atau di perolehnya dalam tahun pajak untuk kepentingan negara dan masyarakat dalam hidup berbangsa dan bernegara sebagai suatu kewjiban yang harus dilaksanakannya.. Penghasilan adalah tambahan kemampuan ekonomis yang diterima atau diperoleh wajib pajak baik yang berasal dari dalam negeri maupun dari luar negeri yang dikelompokkan dalam empat kelompok, yaitu :

a. Penghasilan dari pekerjaan dalam hubungan kerja dan pekerjaan bebas. Contohnya : gaji, honorarium, penghasilan dari praktik dokter, notaris, akuntan, pengacara dan sebagainya.

b. Penghasilan dari usaha dan kegiatan

c. Penghasilan dari modal yang berupa harta gerak maupun harta tidak bergerak, contohnya : bunga, dividen, sewa, keuntungan, penjualan harta atau hak yang tidak digunakan untuk usaha dan sebagainya.

d. Penghasilan lain-lain. Contohnya : pembebasan utang, hadiah dan sebagainya.

\subsubsection{Pendapatan Negara}

Dalam Undang-Undang Nomor 17 Tahun 2003 tentang Keuangan Negara disebutkan bahwa pendapatan negara adalah semua penerimaan yang berasal dari penerimaan perpajakan, penerimaan negara bukan pajak serta penerimaan hibah dari dalam dan luar negeri. Dalam struktur pendapatan negara, Indonesia mempunyai banyak penerimaan dari berbagai sektor diantaranya adalah sektor Minyak dan Gas serta Non Minyak dan Gas (contohnya adalah penerimaan dari sektor pajak, retribusi, hibah, dan lain-lain).

\subsubsection{Pengertian Efektivitas}

Efektivitas digunakan untuk mengukur hubungan antara hasil pungutan suatu pajak dengan tujuan atau target yang telah ditetapkan. Efektivitas merupakan hubungan antara keluaran dengan tujuan atau sasaran yang harus dicapai (Mahmudi, 2010). Dikatakan efektif apabila proses kegiatan mencapai tujuan dan sasaran akhir. Semakin besar ouput yang dihasilkan terhadap pencapaian tujuan dan sasaran yang ditentukan, maka semakin efektif proses kerja suatu unit organisasi. Rasio efektivitas menggambarkan kemampuan pemerintah dalam merealisasikan penerimaan pajak bumi dan bangunan dan pajak penghasilan yang direncanakan dibandingkan dengan target yang ditetapakan berdasarkan potensi riil negara.

\subsubsection{Pengertian Kontribusi}


Menurut kamus ekonomi Guritno (1992) kontribusi adalah sesuatu yang diberikan bersama-sama dengan pihak lain untuk tujuan biaya atau kerugian tertentu atau bersama. Sehingga kontribusi yang dimaksud dapat diartikan sebagai sumbangan yang diberikan oleh pendapatan Pajak Bumi dan Bangunan dan Pajak Penghasilan terhadap besarnya pendapatan negara.

Jika potensi penerimaan pajak pumi dan pangunan dan pajak penghasilan semakin besar dan pemerintah dapat mengoptimalkan sumber penerimaannya dengan meningkatkan target dan realisasi Pajak Bumi dan Bangunan dan Pajak Penghasilan yang berlandaskan potensi sesungguhnya.

\section{METODE PENELITIAN}

\subsection{Ruang Lingkup Penelitian}

Penelitian ini menganalisa efektivitas dan kontribusi penerimaan pajak bumi dan bangunan (PBB) dan pajak penghasilan ( $\mathrm{PPh}$ ) terhadap pendapatan negara. Variabel independen adalah penerimaan pajak bumi dan bangunan dan pajak penghasilan, sedangkan variabel dependen adalah jumlah pendapatan negara di Indonesia.

Ruang lingkup dalam penelitian ini meliputi data Tahun 2007-2017. Data yang digunakan adalah data tahunan dengan jenis data sekunder yaitu data yang didapatkan dari pihak lain yang bersangkutan dalam penelitian ini. Sedangkan, data yang diperlukan dalam penelitian ini adalah data realisasi penerimaan pajak bumi dan bangunan dan pajak penghasilan, targer penerimaan pajak bumi dan bangunan, pajak penghasilan dan pendapatan negara di Indonesia.

\subsection{Metode Pengumpulan Data}

Data yang digunakan dalam penelitian ini adalah data sekunder yang di dapatkan dari pihak-pihak atau instansi yang bersangkutan, informasi dan publikasi yang di dapatkan dari badan pusat statistik, internet, buku, jurnal pada periode 2007 sampai dengan 2017.

Metode pengumpulan data yang digunakan dalam penelitian ini dengan cara observasi dan wawancara pada pihak pegawai pajak.

\subsection{Metode Analisis Data}

Teknik analisa data merupakan salah satu tahap kegiatan penelitian berupa proses penyusunan dan pengolahan data, guna menafsirkan data yang telah diperoleh melalui metode statistik.

Untuk mengetahui efektivitas penerimaan pajak bumi dan bangunan dan kontribusinya terhadap pendapatan negara maka digunakan teknik dalam analisis data sebagai berikut:

1. Membuat tabel penerimaan pajak bumi dan bangunan dan pajak penghasilan dan realisasi pajak bumi dan bangunan dan pajak penghasilan.

2. Menyusun tabel analisis efektifitas pajak bumi dan bangunan dan pajak penghasilan yaitu perbandingan antara penerimaan dan potensi $\mathrm{PBB}$ dan $\mathrm{PPh}$.

Rumus yang digunakan dalam menghitung tingkat efektivitas Pajak Bumi dan Bangunan (PBB) adalah:

Efektivitas Pajak $=\frac{\text { Realisasi penerimaan Pajak }}{\text { Target Penerimaan Pajak }} \times 100 \%$

Sumber: Abdul Halim (2001)

Untuk menilai efektif tidaknya maka dapat dilihat pada tabel dibawah ini: 
Tabel 3.1 Interpretasi Nilai Efektivitas

\begin{tabular}{ll}
\hline Persentase & Kriteria \\
\hline$>100 \%$ & Sangat efektif \\
$90-100 \%$ & Efektif \\
$80-90 \%$ & Cukup efektif \\
$60-80 \%$ & Kurang efektif \\
$<60 \%$ & Tidak efektif \\
\hline
\end{tabular}

Sumber: Depdagri, Kepmendagri No.690.900.327 (1996)

3. Menyusun tabel analisis kontribusi realisasi pajak bumi dan bangunan dan pajak penghasilan terhadap pendapatan negara.

Untuk mengetahui bagaimana dan seberapa besar kontribusi PBB dan PPh, maka untuk mengklasifikasikan kriteria kontribusi PBB dan PPh terhadap Pendapatan Daerah digunakan rumus sebagai berikut:

$$
\text { Konstribusi Pajak }=\frac{\text { Realisasi Penerimaan Pajak }}{\text { Realisasi penerimaan Pendapatan Negara }} \times 100 \% \ldots . .
$$

Sumber: Abdul Halim ( 2001) ini:

Untuk menilai klasifikasi kriteria kontribusi dapat dilihat pada tabel dibawah

Tabel 3.2 Klasifikasi Kriteria Kontribusi

\begin{tabular}{ll}
\hline Persentase & Kriteria \\
\hline $0,00 \%-10 \%$ & Sangat Kurang \\
$10,10 \%-20 \%$ & Kurang \\
$20,10 \%-30 \%$ & Sedang \\
$30,10 \%-40 \%$ & Cukup baik Baik \\
$40,10 \%-50 \%$ & Sangat baik \\
Diatas $50 \%$ & \\
\hline
\end{tabular}

Sumber : Depdagri, Kepmendagri No.690.900.327 (1996)

\section{HASIL DAN PEMBAHASAN}

\subsection{Efektivitas dan Kontribusi Pajak Bumi dan Bangunan dan Pajak Penghasilan}

Perhitungan efektivitas berdasarkan target penerimaan dilakukan dengan cara membandingkan realisasi pemungutan bajak bumi dan bangunan dengan target pemungutan pajak bumi dan bangunan. Pertumbuhan pajak bumi dan bangunan di Indonesia mengalami fluktuasi. 


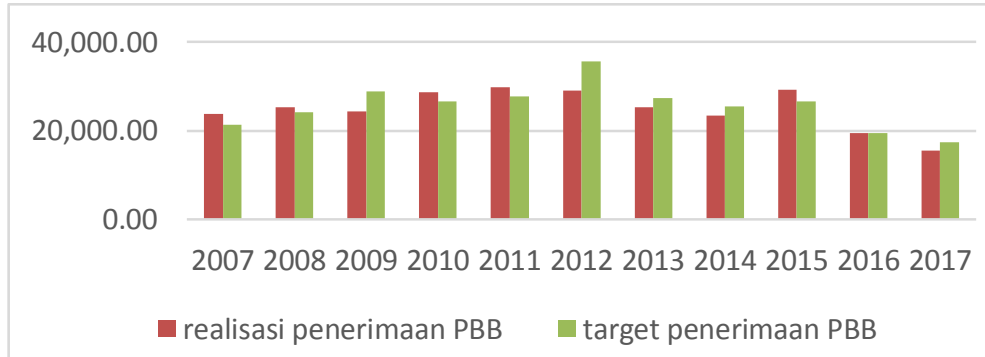

Gambar 4.1 Efektivitas Pajak Bumi dan Bangunan Negara IndonesiaTahun 2007-2017 (Miliyar rupiah)

Sumber: Data diolah (2018)

Berdasarkan gambar 4.1 pada tahun 2007, 2008, 2010, 2011, 2015 menunjukkan angka yang sangat efektif yakni melebihi 100 persen. Pada tahun 2013, 2014, 2016 menunjukkan angka efektif yakni antara 90 persen - 100 persen. Pada tahun 2009, 2012, 2017 menunjukkan angka cukup efektif yakni antara 80 persen - 90 persen. Sehingga dapat disimpulkan bahwa pencapaian keefektifan tertinggi pada tahun 2007 sebesar 112 persen dengan kategori sangat efektif. Sedangkan keefektifan terendah pada tahun 2012 sebesar 81 persen dengan kategori cukup efektif. Rata - rata efektivitas pajak bumi dan bangunan adalah 98 persen dengan kategori efektif menujukkan kecilnya tunggakan pajak dan penghindaran pajak oleh si wajib pajak, dimana rata-rata wajib pajak dapat memenuhi kewajiban pajak. Terjadinya penurunan pajak tahun 2009 dan kenaikan tahun 2010 akibat adanya perubahan tarif PBB perdesaan dan perkotaan itu ditetapkan dari 0,5 persen terhadap nilai jual obyek pajak menjadi paling tinggi 0,3 persen dari NJOP agar dapat memperluas basis pemungutan PBB dalam Undang-undang Nomor 28 tahun 2009 tentang Pajak Daerah dan Retribusi Daerah (PDRD) yang selesai diamandemen pada 15 September 2009 (Kompas.com, 2009). Penurunan pada tahun 2012 terjadi akibat penarikan pajak bumi dan bangunan menjadi kewenangan langsung daerah, Karena diserahkan kepada daerah, maka penurunan tarif PBB ini berbeda-beda di setiap daerah (Kompasiana.com, 2013). Penurunan pada tahun 2016 dan 2017 terjadi akibat pemerintah tengah merencanakan penghapusan PBB untuk bangunan non komersil, alias rumah hunian (Kompas.com, 2015).

Perhitungan kontribusi berdasarkan realisasi penerimaan dilakukan dengan cara membandingkan realisasi pemungutan pajak bumi dan bangunan dengan realisasi penerimaan pendapatan negara.

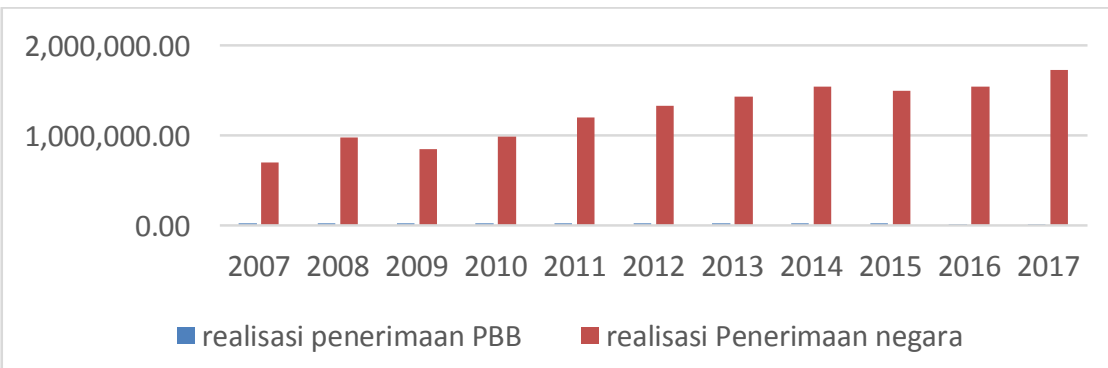

Gambar 4.2 Konstribusi Pajak Bumi dan Bangunan Terhadap Pendapatan Negara Tahun 2007-2017 (Miliyar rupiah)

Sumber: Data Diolah (2018)

Berdasarkan gambar 4.2 kontribusi pajak bumi dan bangunan terhadap pendapatan negara menunjukkan angka yang sangat kurang yaitu kurang dari 10 persen. Sehingga dapat 
disimpulkan bahwa kontribusi terendah pada tahun 2016 dan 2017 yaitu sebesar 1 persen. Dari hasil perhitungan ini dapat diketahui bahwa kontribusi terbesar terjadi pada tahun 2007,2008, 2009 dan 2010 yakni sebesar 3 persen. Sedangkan rata-rata kontribusi pajak bumi dan bangunan adalah sebesar 2 persen yang menurut kriteria berarti sangat kurang atau rendah. Hal ini dikarenakan pajak bumi dan bangunan memiliki jumlah yang relatif kecil sebagai penerimaan negara.

Perhitungan efektivitas berdasarkan target penerimaan dilakukan dengan cara membandingkan realisasi pemungutan pajak penghasilan dengan target pemungutan pajak penghasilan. Pertumbuhan pajak penghasilan di Indonesia hampir mengalami peningkatan di setiap tahunnya.

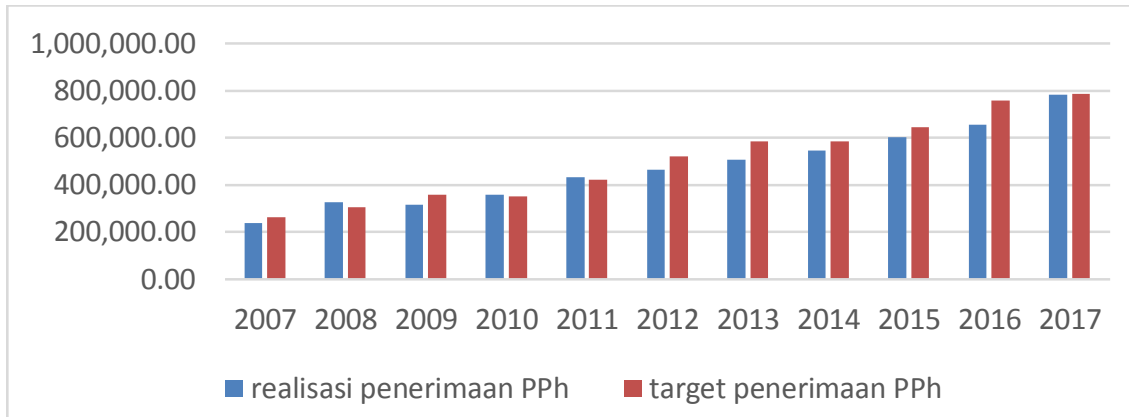

Gambar 4.3 Efektivitas Pajak Penghasilan Negara Indonesia Tahun 2007-2017 (Miliyar rupiah)

Sumber: Data Diolah (2018)

Berdasarkan gambar 4.3 pada tahun 2008, 2010, 2011 menunjukkan angka yang sangat efektif yakni lebih dari 100 persen. Pada tahun 2007, 2014, 2015, 2017 menujukkan angka yang efektif yakni antara 90 persen - 100 persen. Pada tahun 2009, 2012, 2013, 2016 menujukkan angka yang cukup efektif yakni 80 persen - 90 persen. Sehingga dapat disimpulkan efektivitas tertinggi pada tahun 2008 sebesar 107 persen dengan kategori sangat efektif. Sedangkan efektivitas terendah pada tahun 2013 dan 2016 sebesar 87 persen dengan kriteria cukup efektif. Rata - rata efektivitas pajak penghasilan sebesar 95 persen dengan kategori efektif menujukkan kecilnya tunggakan pajak dan penghindaran pajak oleh si wajib pajak, dimana rata -rata wajib pajak dapat memenuhi kewajiban pajak. Naiknya penerimaan pajak pada tahun 2008 karena didukung oleh pergerakan ekonomi selama semester 1 (realisasi pertumbuhan ekonomi 6,2 persen ditambah realisasi inflasi, yakni 11,03 persen) dan adanya upaya pemerintah melalui ekstensifikasi maupun intensifikasi pajak sebasar 20,5 persen (Kompas.com, 2008). Turunnya penerimaan pajak 2009 diakibatkan oleh imbas krisis global dan pelaksanaan stimulus fiskal PPh ditanggung pemerintah yang rendah (Viva.co.id, 2010). Turunnya penerimaan pajak sepanjang 2012 adalah karena pengaruh krisis global terhadap perusahaan di dalam negeri. Krisis global menyebabkan turunnya kinerja penjualan yang berakibat pada anjloknya setoran pajak (Kompas.com, 2012). Naiknya penerimaan pajak tahun 2017 diakibatkan adanya kebijakan tax amnesty yang berpengaruh terhadap peningkatan kepatuhan wajib pajak membayar pajak (Kompas.com, 2017)

Perhitungan kontribusi berdasarkan realisasi penerimaan dilakukan dengan cara membandingkan realisasi pemungutan pajak penghasilan dengan realisasi penerimaan pendapatan negara. 


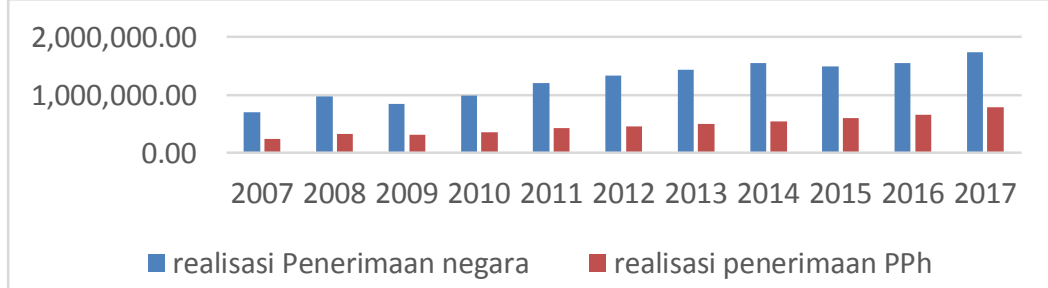

Gambar 4.4 Konstribusi Pajak Penghasilan Terhadap Pendapatan Negara Tahun 20072017

Sumber: Data Diolah (2018)

Berdasarkan gambar 4.4 kontribusi pajak penghasilan terhadap pendapatan negara menunjukkan angka yang cukup baik yaitu lebih dari 30 persen. Sehingga dapat disimpulkan bahwa kontribusi terendah pada tahun 2008 yaitu sebesar 33 persen. Dari hasil perhitungan ini dapat diketahui bahwa kontribusi terbesar terjadi pada tahun 2017 yakni sebesar 45 persen. Sedangkan rata-rata kontribusi pajak penghasilan adalah sebesar 37 persen yang menurut kriteria berarti cukup baik. Hal ini dikarenakan pajak penghasilan merupakan pajak dengan nilai terbesar untuk penerimaan negara.

\subsection{Perbedaan Pajak Bumi dan Bangunan dan Pajak Penghasilan}

Perbedaan antara pajak bumi dan bangunan dan pajak penghasilan dapat dilihat melalui tingkat efektivitas, tingkat kontribusinya dan trend pertumbuhan dari kedua jenis pajak tersebut.

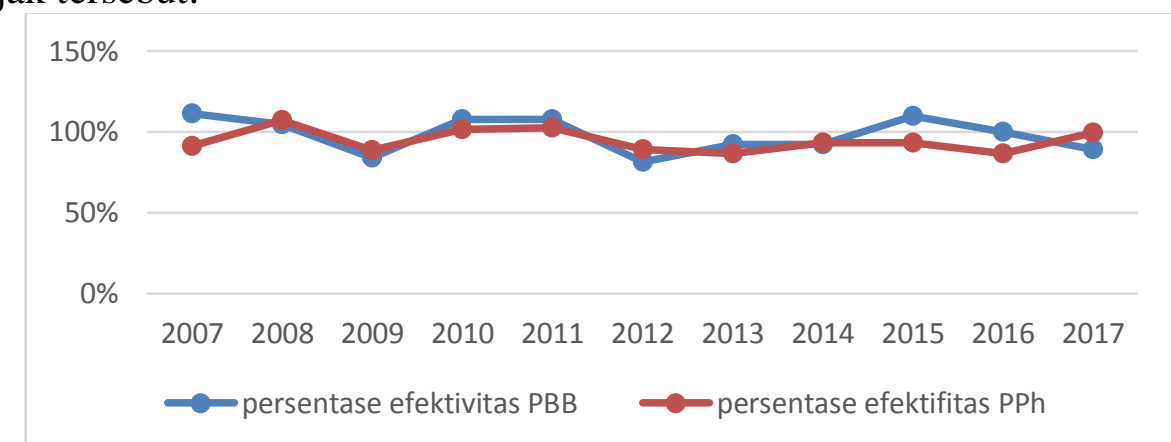

Gambar 4.5 Efektivitas Pajak Bumi dan Bangunan dan Pajak Penghasilan di Indonesia Tahun 2007-2017 (Persen)

Sumber: Data Diolah (2018)

Berdasarkan gambar 4.5 menunjukkan bahwa tingkat efektivitas antara pajak bumi dan bangunan dan pajak penghasilan dari tahun 2008 sampai 2014 menunjukkan hasil yang hampir sama, namun pada tahun 2015 sampai 2017 mengalami perbedaan, yakni pada tahun 2015 dan 2016 tingkat efektivitas pajak penghasilan mengalami penurunan dibawah 90-an persen sementara pajak bumi dan bangunan diatas 100 persen, tetapi pada tahun 2017 pajak bumi dan bangunan mengalami penurunan dibawah 100 persen sementara pajak penghasilan di angka 100 persen. 


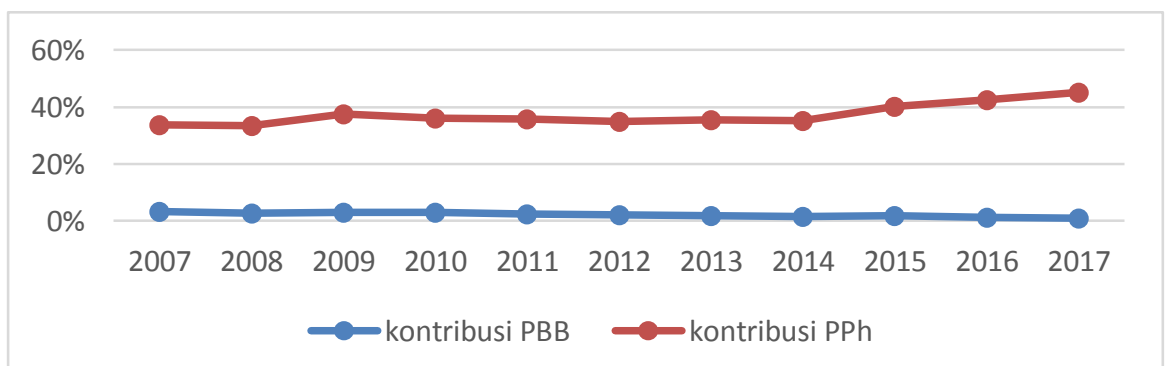

Gambar 4.6 Kontribusi Pajak Bumi dan Bangunan dan Pajak Penghasilan di Indonesia Tahun 2007-2017 (Persen)

Sumber: Data Diolah (2018)

Berdasarkan gambar 4.6 menunjukkan bahwa tingkat kontribusi antara pajak bumi dan bangunan dan pajak penghasilan memiliki perbedaan dimana nilai kontribusi pajak penghasilan dari tahun 2007 sampai dengan 2017 berada diatas 30-an persen dan disetiap tahunnya mengalami kenaikan sementara nilai kontribusi pajak bumi dan bangunan relatif kecil, yakni dibawah 5 persen dan disetiap tahunnya mengalami penurunan.

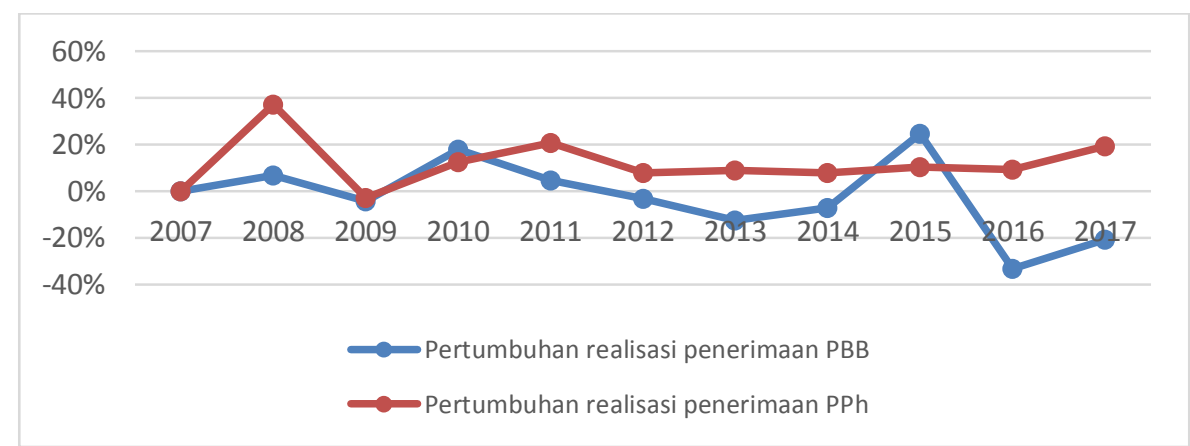

Gambar 4.7 Pertumbuhan Penerimaan Pajak Bumi dan Bangunan dan Pajak Penghasilan Sumber: Data Diolah (2018) di Indonesia Tahun 2007-2017 (Persen)

Berdasarkan Gambar 4.8 menunjukkan bahwa dari tahun 2007-2008 pajak bumi dan bangunan dan pajak penghasilan pertumbuhannya mengalami peningkatan yakni masingmasing 7 persen dan 37 persen. Pada tahun 2009 keduanya turun sebesar 3 persen. Pada tahun 2010 dan 2011 mengalami peningkatan. Pada tahun 2012 sampai dengan 2017 pajak penghasilan terus mengalami peningkatan yang cukup stabil sementara pajak bumi dan bangunan didominasi terjadinya penurunan, tetapi hanya pada tahun 2015 yang terjadi peningkatan, yakni sebesar 25 persen.

\section{KESIMPULAN}

Berdasarkan hasil penelitian dan pembahasan yang sudah dilakukan mengenai tingkat efektivitas dan kontribusi Pajak Bumi dan Bangunan dan Pajak Penghasilan terhadap Pendapatan Negara dapat disimpulkan bahwa :

1.a) Tingkat efektivitas dan kontribusi penerimaan Pajak Bumi dan Bangunan tahun 2007 sampai dengan 2017 dikatakan efektif dengan rata-rata persentase sebesar 98 persen. Hal-hal yang mempengaruhinya antara lain kebijakan pemerintah (tarif pajak, peraturan pemerintah, dan lain-lain), bencana alam, jumlah objek dan subjek pajak seperti pada tahun 2009 dan 2012 terjadinya penurunan yang diakibatkan adanya kebijakan penurunan tarif pajak bumi dan bangunan, kemudian terjadi juga pada 
tahun 2016 dan 2017, yakni adanya rencanakan penghapusan PBB untuk bangunan non komersil, alias rumah hunian. Namun, dari segi kontribusinya masih sangat kurang dikarenakan jumlahnya relatif kecil sebagai penerimaan negara, yakni rata-rata sebesar 2 persen.

b) Tingkat efektivitas penerimaan Pajak Penghasilan tahun 2007 sampai dengan 2017 dikatakan efektif dengan rata-rata 95 persen. Hal-hal yang mempengaruhinya antara lain kebijakan pemerintah (tarif pajak, peraturan pemerintah, dan lain-lain), perekonomian global, kepatuhan wajib pajak yang berpenghasilan seperti pada tahun 2009 dan 2008 terjadinya penurunan karena adanya krisis global, pada tahun 2017 terjadinya kenaikan karena adanya kebijakan pemerintah, yaitu tax amnesty. Jika dilihat dari besaran kontribusinya termasuk kriteria yang cukup baik, yakni rata-rata sebesar 37 persen. Hal ini dikarenakan pajak penghasilan merupakan pajak dengan nilai terbesar untuk penerimaan negara.

2. Perbedaan antara pajak penghasilan dan pajak bumi dan bangunan dari segi efektivitas keduanya mengalami fluktuasi, tetapi masih dapat dikatakan efektif karena rata-rata keduanya berada di atas 90 persen. Pada kontribusinya memiliki banyak perbedaan dimana pajak penghasilan hampir setiap tahunnya mengalami peningkatan dan nilai kontribusi cukup baik, yakni rata-rata 37 persen sementara pajak bumi dan bangunan hampir setiap tahunnya mengalami penurunan dan nilai kontribusinya sangat kurang, yakni rata-rata dibawah 3 persen. Pada tingkat pertumbuhannya kedua pajak tersebut mengalami fluktuasi dimana pajak penghasilan didominasi terjadinya peningkatan hampir disetiap tahunnya sementara pajak bumi dan bangunan didominasi terjadinya penurunan.

\section{UCAPAN TERIMAKASIH}

Penulis mengucapkan terimakasih yang sebesar-besarnya kepada bapak M. Faisal Akbar, S.E., M.S.E selaku dosen pembimbing dalam penyusunan jurnal ini sehingga dapat selesai dengan baik.

\section{DAFTAR PUSTAKA}

Badan Pusat Statistik, 2018. Realisasi Penerimaan Negara (Milyar Rupiah), 2007-2017. Badan Pusat Statistik, 2017. Anggaran Pendapatan Negara (miliar rupiah), 2007-2017. https://www.liputan6.com/bisnis/read/2212865/jumlah-wajib-pajak-yang-melaporkan-sptpph-2015-naik-17. Di akses 31 Oktober 2018 https://ekonomi.kompas.com/read/2015/04/07/034900926/Penghapusan.Pajak.Bumi.dan.Ban gunan.Tahun.2016. Diakses 27 Oktober 2018

https://www.kajianpustaka.com/2012/10/pajak-penghasilan.html. Tahun 2012. Diakses 8 November 2018

https://www.academia.edu/31892316/Pendapatan Nasional Pertumbuhan Dan Struktur Ekonomi Indonesia. Diakses 8 November 2018

https://nasional.kompas.com/read/2009/10/12/07133582/tarif pbb turun jadi 03 persen. Tahun 2009. Diakses 9 November 2018

https://www.kompasiana.com/ryanmintaraga/552b92bf6ea834b51c8b458c/tarif-pbb-turun-

90-kenapa. Tahun 2013. Diakses 10 November 2018

https://tekno.kompas.com/read/2008/07/09/2022252/penerimaan.pajak.semester.1.2008.naik. 50.persen. Tahun 2008. Diakses 12 November 2018

https://www.viva.co.id/arsip/118316-2009-penerimaan-pajak-tak-capai-target. Tahun 2010. Diakses 12 November 2018 
https://nasional.kompas.com/read/2013/01/14/20281320/ini.penyebab.penerimaan.pajak.2012 .tidak.capai.target. Tahun 2013. Diakses 15 November 2018

https://ekonomi.kompas.com/read/2017/05/05/230616826/penerimaan pajak melonjak Tahun 2017. Diakses 17 November 2018

Kamus Besar Bahasa Indonesia 2017, Pengertian Kontribusi, Diakses 4 September 2017, dari www.kbbi.web.id

Mahmudi. 2010. Analisis Laporan Keuangan Pemerintah Daerah. Sekolah Tinggi Ilmu Manajemen. Yogyakarta

Mokamat. 2009. Analisis faktor yang mempengaruhi Efektivitas Penarikan Pajak Bumi dan Bangunan di Kabupaten Grobogan. Universitas Diponegoro Semarang.

Sari, Yulia Anggara. 2011. Analisis Efektivitas dan Kontribusi Penerimaan Pajak Bumi dan Bangunan terhadap Pendapatan Daerah Di Kota Bandung. Universitas Pendidikan Indonesia.

Undang-Undang Nomor 17 Tahun 2003 tentang Keuangan Negara

Undang-Undang no 12 tahun 1994 tentang Pajak Bumi dan Bangunan 